\title{
Hubungan Interpersonal Skill Karyawan terhadap Minat Masyarakat Muslim Menjadi Anggota Koperasi Syari'ah
}

\author{
Sisco Farnandes \\ Program Studi Perbankan STAIN Curup, Bengkulu \\ Email: siscofarnandes@gmail.com
}

\section{Hardivizon}

Sekolah Tinggi Agama Islam Negeri Curup, Bengkulu

Email: hardivizon@gmail.com

\begin{abstract}
The interpersonal skill is an ability to identify and respond a reasonable emotion, act, behaviour, motivation and desire of human being. It is sophisticated and need-skill in routine life. In fact, no one of individu can be isolated from the others. Each others need to others. To operate it, individu must have an specific ability to understand the others. In this context, the study is elaborated through mixed-methodology, the research sucessfully find some points. One of these is that, there is, clear and significant correlation between interpersonal skill and the interest of consumers of Islamic Koperasi, Barakoh of Curup.
\end{abstract}

Keywords: Interpersonal Skill, reasonable Emotion, Motivation, and Interest of Consumers.

\begin{abstract}
Abstrak
Interpersonal skiil (kemampuan interpersonal) merupakan kemampuan mengenali dan merespon secara layak perasaan, sikap dan perilaku, motivasi serta keinginan orang lain.Kemampuan ini sangat diperlukan karena di dalam kehidupan sehari-hari hampir tidak mungkin manusia tidak berhubungan dengan orang lain. Dalam skema hidup bersama muncul kebutuhan untuk memahami kebutuhan manusia lain, hal ini pula berlaku dalam sistem keanggotaan koperasi syari'ah guna untuk meningkatkan minat calon anggota dan anggota yang lama agar memiliki loyalitas dan ketertarikan untuk terus bekerja sama dengan lembaga koperasi syari'ah.Penelitian lapangan (field research) ini menggunakan pendekatan kuantitatif deskriptif dan diperkuat oleh pendekatan kualitatif dengan menggunakan in-depth interview (wawancara) dalam menganalisa fenomena yang terjadi. Temuan dari penelitian ini adalah terdapat hubungan yang signifikan secara parsial antara interpersonal skill karyawan terhadap minat menjadi anggota koperasi syari'ah.
\end{abstract}

Kata Kunci : Interpersonal Skill, Perasaan yang layak, Motivasi, dan Kostumer Interes 


\section{Pendahuluan}

Di era globalisasi seperti saat ini tidak hanya koperasi konvensional yang berkembang, tetapi sudah banyak bermunculan koperasi berbasis syari'ah. Seperti halnya perbankan syari'ah, koperasi syari'ah juga mulai diminati oleh masyarakat. Koperasi syari'ah merupakan lembaga pendukung kegiatan ekonomi masyarakat kecil golongan ekonomi lemah dengan berlandaskan sistem ekonomi syari'ah Islam.

Salah satu koperasi syari'ah yang berkembang di Kabupaten Rejang Lebong adalah Koperasi Syari'ah Barokah Curup yang berkantorkan di Jln. Iskandar Ong No.68 Kel. Timbul Rejo Curup. Koperasi Syari’ah Barokah Curup kini telah memiliki kantor sendiri dan ruko yang disewakan kepada anggota diantaranya laundry L\&L serta usaha jahit pakaian (tailor). Koperasi Syari'ah Barokah Curup juga memiliki unit usaha, diantaranya unit simpan pinjam dan tabungan yang memudahkan bagi para anggotanya. Lembaga ini bertujuan untuk menyejahterakan para anggotanya dengan tetap memegang prinsip dan nilai dalam koperasi serta landasan secara syari'ah.

Peran anggota dalam mengembangkan koperasi syari'ah sangatlah besar karena merupakan salah satu faktor pendukung keberlangsungan Koperasi Syari'ah Barokah Curup yang harus selalu dihadirkan. Karena tanpa adanya anggota, maka dapat dipastikan bahwa kegiatan operasional lembaga koperasi syari'ah tersebut tidak akan berjalan dengan lancar. Dengan demikian pihak koperasi syari'ah harus memiliki kiat khusus agar dapat meningkatkan minat calon anggota dan anggota yang lama agar memiliki loyalitas dan ketertarikan untuk terus bekerja sama dengan lembaga koperasi syari'ah. Kemampuan ini dinamakan interpersonal skill.

Menurut Badan Pengawasan Keuangan dan Pembangunan (BPKP) bahwa keterampilan interpersonal (interpersonal skill) adalah keterampilan untuk mengenali dan merespon secara layak perasaan, sikap dan perilaku, motivasi serta keinginan orang lain. Bagaimana diri kita mampu membangun hubungan yang harmonis dengan memahami dan merespon manusia atau orang lain merupakan bagian dari keterampilan interpersonal. ${ }^{2}$

Dalam buku Multiple Intelligences, mengungkapkan 7 (tujuh) kecerdasan atau keterampilan yang dimiliki manusia salah satunya adalah keterampilan untuk memahami dan berkomunikasi dengan orang lain serta melihat mood,

Wib.

${ }^{1}$ Ade Fitri, Bendahara, Koperasi syari'ah barokah, wawancara, 11 Februari 2016, 08:10 2007), 2.

${ }^{2}$ R.Bramantyo dan Agus Tri Prasetyo, Interpersonal Skill, (Bogor: Pusiklatwas BPKP, 
temperamen, dan motivasi guna membentuk dan menjaga hubungan antar manusia, keterampilan ini disebut juga keterampilan interpersonal (interpersonal skill). ${ }^{3}$

Sedangkan menurut Linda Yani Pusfiyaningsih, interpersonal skill adalah kemampuan, kepandaian, keterampilan seseorang dalam mengerjakan sesuatu, percaya diri dalam mengasah kemampuan berkomunikasi dan meningkatkan buman relations dalam kehidupan bermasyarakat. ${ }^{4}$

Dari teori-teori diatas dapat dipahami bahwa keterampilan interpersonal itu sangat diperlukan karena di dalam kehidupan sehari-hari hampir tidak mungkin manusia tidak berhubungan dengan orang lain. Dalam skema hidup bersama muncul kebutuhan untuk memahami kebutuhan manusia lain, hal ini pula berlaku dalam sistem keanggotaan koperasi syari'ah.

Kesadaran akan pentingnya interpersonal skill agar pihak koperasi dapat membangkitkan, mengarahkan, menjaga, menunjukkan intensitas bersifat terus menerus dengan tujuan untuk memberikan motivasi bagi calon anggota maupun anggota. Hal tersebut dapat berupa sikap, pelayanan yang diberikan, cara pihak koperasi syari'ah menjelaskan produk yang dimiliki maupun cara pihak koperasi syari'ah dalam menata ruang kantor agar anggota memiliki kepercayaan terhadap pihak koperasi syari'ah dan produk yang ditawarkan kepada calon anggota maupun anggota.

Berdasarkan observasi awal peneliti bahwa kemampuan interpersonal skill dalam membangun keanggotaan di Koperasi Syari'ah Barokah Curup telah dimiliki dan diterapkan oleh karyawan koperasi tersebut hanya saja kurang begitu nampak. Oleh karenanya penulis ingin menguji seberapa besar hubungan interpersonal skill ini dalam keanggotaan. Sehingga berdasarkan uraian diatas maka penulis tertarik untuk melakukan penelitian yang berjudul: "Hubungan Interpersonal skill Karyawan Terhadap Minat Masyarakat Muslim Menjadi Anggota Di Koperasi Syari'ah (Studi Kasus Koperasi Syari'ah Barokah)." Berdasarkan latar belakang penelitian yang telah diuraikan, maka rumusan masalah yang diteliti adalah : Pertama, apakah terdapat hubungan yang signifikan secara parsial antara interpersonal skill karyawan yang terdiri dari atribut variabel berupa komunikasi interpersonal dan kesadaran diri terhadap minat masyarakat muslim menjadi anggota di Koperasi Syari'ah Barokah? Kedua, Apakah terdapat hubungan yang signifikan secara simultan antara interpersonal skilkkaryawan yang terdiri dari atribut variabel berupa komunikasi interpersonal dan kesadaran diri

${ }^{3}$ Linda Campbell, et al, Teabching \& Learning Through Mutiple Intelligences, (Depok: Inisiasi Press, 2002), 172.

${ }^{4}$ Linda Yani Pusfiyaningsih, "interpersonal skills", bttp://slideplayer.info/slide/3044809/, diakses pada 20 Januari 2016. 
terhadap minat masyarakat muslim menjadi anggota di Koperasi Syari'ah Barokah? Ketiga, Apakah ada faktor selain interpersonal skillkaryawan yang dapat berimplikasi terhadap minat masyarakat muslim menjadi anggota di Koperasi Syari'ah Barokah?

\section{Interpersonal Skill: Sebuah Tinjaun Teoritis}

\section{Pengertian interpersonal skill}

Interpersonal skill (keterampilan interpersonal) didefinisikan sebagai keterampilan untuk mengenali dan merespon secara layak perasaan, sikap, perilaku dan motivasi serta keinginan orang lain. Bagaimana diri kita mampu membangun hubungan yang harmonis dengan memahami dan merespon manusia atau orang lain merupakan bagian dari interpersonal skill. ${ }^{5}$

Dalam buku Multiple Intelligences, mengungkapkan 7 kecerdasan atau keterampilan yang dimiliki manusia salah satunya adalah keterampilan untuk memahami dan berkomunikasi dengan orang lain serta melihat mood, temperamen, dan motivasi guna membentuk dan menjaga hubungan antar manusia, keterampilan ini disebut juga keterampilan interpersonal(interpersonal skill). ${ }^{6}$ Menurut Badan Pengawasan Keuangan dan Pembangunan (BPKP) interpersonal skill memiliki dua indikator yang penting yaitu komunikasi interpersonal dan kesadaran diri.

\section{Pengertian Komunikasi Interpersonal}

Dalam hidup keseharian hampir tidak mungkin manusia tidak berhubungan dengan orang lain. Sudah merupakan hukum alam bahwa manusia adalah mahluk sosial, artinya manusia harus hidup bersama dengan manusia lainnya. Dalam skema hidup bersama ini muncul kebutuhan untuk memahami kebutuhan manusia lain, maka timbullah komunikasi antar manusia.

Menurut Devito seperti yang dikutip oleh Yayan, komunikasi interpersonal adalah penyampaian pesan oleh satu orang dan penerimaan pesan oleh orang lain atau sekelompok kecil orang, dengan berbagai dampaknya dan dengan peluang untuk memberikan balik segera. Dan menurut McDavid \& Harari komunikasi interpersonal yaitu proses komunikasi yang ber-setting pada objek-objek social untuk mengetahui pemaknaan suatu stimulus yang berupa 2007), 2

${ }^{5}$ R.Bramantyo dan Agus Tri Prasetyo, Interpersonal Skill, (Bogor: Pusiklatwas BPKP,

${ }^{6}$ Linda Campbell, et al, Teabching \& Learning Through Mutiple Intelligences, (Depok: Inisiasi Press, 2002), 172. 
informasi atau pesan. ${ }^{7}$ Komunikasi interpersonal adalah interaksi tatap muka antar dua orang atau beberapa orang, dimana pengirim dapat menyampaikan pesan secara langsung dan penerima pesan dapat menerima dan menanggapi secara langsung pula. ${ }^{8}$ Komunikasiinterpersonal sendiri dapat berlangsung dalam format bahasa verbal maupun bahasa nonverbal. ${ }^{9}$ Hal tersebut bermakna: Pertama, bahasa verbal adalah proses berkomunikasi berkaitan dengan kata dan makna, berbahasa dan berfikir. Kedua, bahasa nonverbal mencakup segala sesuatu yang tidak disadari dalam bentuk gerak, isyarat, gerak tubuh, raut muka, nada atau getaran suara dan tarikan napas.

\section{Pengertian Kesadaran Diri}

Kesadaran diri bukan hanya salah satu syarat agar kita sukses, tetapi juga merupakan syarat agar kita dapat bekerja bersama orang lain secara efektif. Sudah terbukti bahwa seorang karyawan yang baik adalah seorang yang dapat menyadari kekuatan dan kelemahan dirinya. Kesadaran diri adalah pengetahuan diri dalam menentukan langkah awal agar dapat bekerja dengan efektif. "yang menentukan kualitas hidup bukanlah seberapa banyaknya pengalaman tetapi seberapa banyaknya kesadaran akan apa yang kita alami." dapat memahami diri adalah dengan mengenali: kekuatan dan kelemahan diri; perilaku; pola pikir; nilai diri; dan pengungkapan diri, adapun penjelasannya sebagai berikut:

1) Kekuatan dan kelemahan diri ${ }^{11}$

Untuk dapat melampaui setiap tantangan dan ujian hidup, sang Maha Pencipta telah membekali empat anugerah yaitu kemampuan akal, emosi, fisik, dan spiritual, sangat jarang ditemui seseorang yang memiliki keseimbangan kemampuan pada keempat anugrah itu, tetapi yang terpenting adalah bagaimana kita memahami dan menyadari kekuatan dan kelemahan akal, emosi, fisik, dan spiritual yang kita miliki untuk kemudian kita kembangkan. Sebagai makhluk sosial dan spiritual maka alangkah baiknya bila kita dapat meningkatkan keempat anugrah tersebut secara seimbang.

${ }^{7}$ Herdiyan Maulana dan Gumgum Gumelar, Psikologi Komunikasi dan Persuasi, Jakarta Barat: @kademia, 2013), 75.

${ }^{8}$ Agus Hardjana, Komunikasi Interpersonal Dan Intrapersonal, (Yogyakarta: Kanisius, 2003), 86.

${ }^{9}$ Bramantyo, Op. Cit., 26. 2007), 12.

${ }^{10}$ R.Bramantyo dan Agus Tri Prasetyo, Interpersonal Skill, (Bogor: Pusiklatwas BPKP, ${ }^{11}$ Ibid., 16. 
2) Perilaku ${ }^{12}$

Perilaku adalah cara kita menunjukkan diri. Bagi kebanyakan orang perilaku adalah sesuatu yang susah diubah bahkan ada yang meyakini bahwa perilaku seseorang tidak bisa diubah, karena perilaku seseorang adalah sesuatu yang terbentuk selama usianya. Menurut KBBI perilaku adalah tanggapan atau reaksi terhadap rangsangan atau lingkungan. ${ }^{13}$

Unsur-unsur yang membentuk perilaku sebagai berikut:

a) Emosi: adalah reaksi perasaan manusia atas berbagai situasi yang dihadapinya, dapat berupa takut, senang, sedih, marah, dan sayang.

b) Motivasi: adalah mencapai sesuatu dengan bergerak, mengambil tindakan dan kerja nyata untuk mewujudkan apa yang diinginkan.

3) Pola pikir ${ }^{14}$

Pola pikir adalah cara otak kita memproses berbagai informasi yang diterima, bagaimana kita menganalisis informasi dan membuat sebuah keputusan tentang bagaimana menggunakan dan mengaplikasikan informasi tersebut. Sebuah pola pikir terbentuk oleh pengalaman hidup dan lingkungan seseorang. Sebuah pola pikir akan menciptakan prasangka diri dan persepsi diri, yang selanjutnya sangat memengaruhi pola tindak dan pola interaksi seseorang. Setidaknya ada beberapa konsep penting terkait asumsi tersebut, yakni: Pertama, persepsi, dimana persepsi adalah sesuatu proses seseorang menerima informasi serta memberikan arti atas informasi yang diterimanya. Kedua, pola tindak dimana pola tindakan yang kita lakukan dalam sesuatu kondisi atau bagaimana respon kita atas sebuah kejadian, orang, pemikiran dan perasaan. Ketiga, pola interaksi dimana pola interaksi adalah cara bagaimana kita mengomunikasikan ide, pendapat perasaan dengan orang lain.

4) Nilai diri ${ }^{15}$

Nilai diri adalah sesuatu yang dipegang teguh oleh seseorang dan ditetapkan sebagai sebuah prinsip hidup karena diyakini dapat membantu dalam kehidupannya. Nilai diri juga dapat memengaruhi sikap hidup seseorang dalam menghadapi setiap hal.

\footnotetext{
${ }^{12}$ Ibid.

${ }^{13}$ Kamus Besar Bahasa Indonesia, (Jakarta: Pustaka Phoenix, 2007), 693.

${ }^{14}$ R.Bramantyo, Op. Cit., 21.

${ }^{15}$ Ibid., 24.
} 


\section{Tinjauan Mengenai Minat}

Secara sederhana, minat (interest) berarti kecenderungan dan kegairahan yang tinggi atau keinginan yang besar terhadap sesuatu. ${ }^{16}$ Menurut Kamus Besar Bahasa Indonesia (KBBI), minat adalah sebuah perhatian, kesukaan dan kecenderungan hati. ${ }^{17}$ Minat juga dapat diartikan keinginan dan dorongan yang muncul dari dalam diri atau dari luar diri (lingkungan) yang menjadi faktor penggerak ke arah tujuan yang ingin dicapai. ${ }^{18}$

Sedangkan menurut para ahli pengertian minat sebagai berikut: menurut Kartono adalah momen dari kecenderungan yang terarah secara intensif kepada satu objek yang dianggap penting. Minat ini erat berkaitan dengan kepribadian dan selalu mengandung unsur efektif/perasaan , kognitif dan kemauan. ${ }^{19}$ Menurut M. Ngalim Purwanto, minat adalah suatu yang mengarah kepada suatu tujuan dan merupakan dorongan bagi perbuatan. ${ }^{20}$ Dapat disimpulkan bahwa pengertian dari minat adalah keinginan, kehendak dan kesukaan seseorang terhadap tujuan yang diminati.

\section{Faktor-faktor yang Memengaruhi Minat}

Minat seseorang tidak timbul secara tiba-tiba. Minat tersebut ada karena pengaruh dari beberapa faktor. Faktor-faktor yang memengaruhi minat, antara lain:

a. Faktor internal ${ }^{21}$

Faktor internal yang dapat memengaruhi minat pada seseorang antara lain: Pertama, keinginan untuk dapat memiliki keinginan untuk dapat memiliki sesuatu dapat mendorong seseorang untuk melakukan pekerjaan untuk tujuannya tersebut. Kedua, keinginan untuk dapat hidup. Keinginan untuk dapat hidup merupakan kebutuhan setiap manusia yang hidup di muka bumi ini. Untuk mempertahankan hidup ini orang mau melakukan apa saja. Ketiga, Keinginan untuk memperoleh penghargaan. Seseorang mau bekerja disebabkan adanya keinginan untuk di akui, dihormati orang lain. Untuk memiliki status yang lebih tinggi. Keempat, Keinginan untuk memperoleh

${ }^{16}$ Muhibbin Syah, Psikologi Pendidikan, (Bandung: Remaja Rosdakarya, 2009), 133.

${ }^{17}$ Kamus Besar Bahasa Indonesia, (Jakarta: Pustaka Phoenix, 2007), 586.

${ }^{18}$ Etta Mamang Sangadji dan Sopiah, Perilaku Konsumen,(Yogyakarta: Andi Offset, 2013),

155.

${ }^{19}$ Kartini Kartono, Psikologi Umum, (Bandung: Mandar Sari, 1996), 112.

${ }^{20}$ M. Ngalim Purwanto, Psikologi Pendidikan, (Bandung: Remaja Rosdakarya, 1990), 56.

${ }^{21}$ Edi Sutrisno, Manajemen Sumber Daya Manusia, (Jakarta: Kencana, 2012), 116-117. 
pengakuan. Kelima, keinginan untuk memperoleh pengakuan itu dapat meliputi:

1) Adanya penghargaan terhadap prestasi.

2) Adanya hubungan yang harmonis dan kompak.

b. Faktor eksternal

Faktor eksternal juga tidak kalah peranannya dalam memengaruhi minat seseorang. Faktor-faktor eksternal tersebut, yakni: ${ }^{22}$

1) Kondisi lingkungan kerja. Keseluruhan sarana prasarana yang ada di sekitar karyawan yang dapat memengaruhi pelaksanan pekerjaan.

2) Status dan tanggung jawab. Status dan kedudukan merupakan dorongan untuk memenuhi kebutuhan sense of achievement, sehingga yang diberi kepercayaan dapat memberikan tanggung jawabnya.

3) Peraturan yang fleksibel. Peraturan yang berlaku dan bersifat mengatur dan melindungi karyawan atau anggota. Semua ini merupakan aturan main yang mengatur hubungan antara karyawan dengan perusahaan.

\section{Metodologi Penelitian}

Dalam penelitian ini peneliti menggunakan pendekatan kuantitatif deskriptif dengan mengolah data berupa angka yang didapat dari kuisioner dan kemudian dideskripsikan serta disimpulkan dari hasil data tersebut guna mengetahui signifikasi hubungan interpersonal skill karyawan terhadap minat anggota di Koperasi Syari'ah Barokah.Data yang diambil dilakukan secara sampel acak sederhana (simplerandom sampling) dengan cara melihat daftar anggota koperasi syariah dan dijadikan sebagai kerangka sampel, dengan seluruh anggota koperasi yang beragama muslim sebanyak 255 orang, makamenurut Arikunto apabila populasi kurang dari 100, maka lebih baik diambil semua sebagai sampel, selanjutnya jika populasi diatas 100 maka dapat diambil sampel 10\%-15\% dari populasi. Dari teori tersebut maka peneliti mengambil sampel sebanyak 15\% dari jumlah populasi yang ada sehingga diperoleh sebanyak 38 orang.

Dalam penelitian ini, jenis data yang diperlukan berupadata primer yang diperoleh secara langsung dari obyek penelitian (para responden) yang telah ditentukan di dalam instrumen penelitian yang berasal dari hasil angket (kuisioner) kepada anggota Koperasi Syariah Barokah yang beragama Islam sedangkan data sekunder Data sekunder merupakan data yang diperoleh dari 
wawancara dengan melakukan interview kepada karyawan dan pengurus Koperasi Syari'ah Barokah yang berkaitan dengan masalah penelitian dan juga sumber-sumber tertulis yang terkait dan mendukung penelitian baik dari bukubuku, jurnal, modul dan penelitian terdahulu sebagai pendukung penelitian.

Untuk mendapatkan dan menghimpun data di lapangan penulis menggunakan beberapa teknik pengumpulan data berupa observasi dengan melakukan pengamatan secara langsung dan menganalisis terhadap objek penelitian, yakni karyawan dan anggota Koperasi Syari'ah Barokah kemudianpeneliti memberikan kuisioner kepada 38 anggota seperti yang telah dijelaskan sebelumnya di sampel peneliti secara acak sebagai sampel penelitian dengan alternatif jawaban yang tersedia serta melakukan wawancara mendalam (in-depth interview) dengan beberapa pihak terkait untuk lebih mendalami temuantemuan dari hasil kuisioner. Wawancara mendalam akan peneliti lakukan untuk mendapatkan data yang lebih akurat.

Dalam penelitian ini juga peneliti menggunakan beberapa tahap dan pendekatan teknik analisis data kuantitatif berupa uji validitas dan reliabilitas instrument, pendekatan teknik analasis data dengan uji asumsi klasik, analisis regresi linier berganda, uji hipotesis serta Uji Koefisien Determinasi. Adapun dalam penelitian inijika dirasa perlu penulis juga akan menggunakan pendekatan teknik analisis data kualitatif. Dengan menggunakan in-depth interview dalam menganalisa fenomena yang terjadi dan juga peneliti menggunakan analisis deskriptif kualitatif. Metode deskriptif adalah suatu analisa dengan memberikan gambaran dan melaporkan apa adanya dengan proses analisa data-data yang diperoleh dalam penelitian. ${ }^{23}$ Metode deskriptif juga dalam hal ini meneliti status sekelompok manusia, suatu objek, suatu set kondisi, suatu sistem pemikiran ataupun suatu kelas peristiwa pada masa sekarang. Tujuan dengan penelitian deskriptif ini adalah untuk membuat deskripsi, gambaran atau lukisan secara sistematis, faktual dan akurat mengenai fakta-fakta, sifat-sifat serta hubungan antar fenomena yang diselidiki. ${ }^{24}$ Dan dalam penelitian ini data-data yang diperoleh dari proses wawancara mendalam (in-depth interview) dituangkan ke dalam tulisan yang berupa deskripsi dari hasil pengambilan data tersebut.

${ }^{23}$ Husaini Usman Dan Purnomo Setiadi, Metode Penelitian Sosial, (Jakarta: Bumi Aksara, 2001), 20.

${ }^{24}$ Moh.Nazir, Metode Penelitian. (Jakarta: Ghalia Indonesia.1988), 63. 


\section{Korelasi antara Interpersonal Skill, Kesadaran Diri dan Minat Menjadi Nasabah}

Dalam penelitian ini, peneliti menggunakan sampel sebanyak 38 responden dengan populasi anggota Koperasi Syari'ah Barokah yang mencapai 255 anggota. Dalam hal ini, peneliti menggunakan tingkat kesalahan sebesar 5\% dan diperoleh sampel sebanyak 38 responden. Dari sampel tersebut maka peneliti menggunakan teknik random sampling sehingga responden atau anggota memiliki kesempatan yang sama untuk menjadi sampel penelitian.

Untuk mengetahui pengaruh komunikasi interpersonal dan kesadaran diri karyawan terhadap minat masyarakat muslim menjadi anggota, peneliti menggunakan kuesioner yang telah disebar kepada anggota. Data yang diperoleh diuji dengan SPSS untuk mengetahui valid dan reliabel semua indikator variabel penelitian. Nilai Corrected Item Total lebih besar dari r tabel yakni 0.3202 yang berartimenunjukkan bahwa seluruh indikator variabel memiliki konstruk yang kuat. Selanjutnya masing-masing variabel memiliki Cronbach Alpha> 0.60, sehingga dapat dikatakan indikator tersebut reliabel. Adapun hasil yang didapatkan dari variabel interpersonal skill karyawan secara parsial yang terdiri dari atribut variabel berupa komunikasi interpersonal dan kesadaran diri terhadap minat masyarakat muslim menjadi anggota di Koperasi Syari'ah Barokah, memperoleh hasil sebagai berikut:

1) Komunikasi interpersonal secara parsial

a) Hasil uji hipotesis yang diperoleh untuk menguji pengaruh komunikasi interpersonal karyawan terhadap minat menjadi anggota menunjukkan bahwa variabel komunikasi interpersonal karyawan memiliki $t_{\text {hitung }}$ (3.313) $>t_{\text {tabel }}$ (2.03011) dengan nilai Sig. sebesar 0.002 dengan alpha 5\%. Maka dapat diperoleh kesimpulan bahwa komunikasi interpersonal karyawan memiliki pengaruh yang signifikan terhadap minat masyarakat muslim menjadi anggota di Koperasi Syari'ah Barokah.

b) Dalam analisa regresi linier berganda diperoleh hasil nilai Sig. 0.002 dengan alpha $5 \%$ dan nilai beta dalam unstandardized coefficients variabel komunikasi interpersonal karyawan menunjukkan angka sebesar 0.655 , artinya pada saat komunikasi interpersonal karyawan meningkat 1 satuan, maka besarnya minat adalah sebesar 0.655 satuan. Sehingga dapat disimpulkan bahwa variabel komunikasi interpersonal karyawan mempunyai pengaruh positif terhadap minat masyarakat muslim menjadi anggota di Koperasi Syari'ah Barokah. 
2) Kesadaran diri secara parsial

a) Pengaruh kesadaran diri karyawan terhadap minat masyarakat muslim menjadi anggota yang diuji dengan program SPSS diperoleh hasil variabel kesadaran diri memiliki $\mathrm{t}_{\text {hitung }}(3.633)>$ memiliki $\mathrm{t}$ tabel (2.03011) dengan nilai Sig. sebesar 0.001 dengan alpha 5\%. Dengan demikian dapat disimpulkan bahwa variabel kesadaran diri karyawan berpengaruh secara signifikan terhadap minat masyarakat muslim menjadi anggota di Koperasi Syari'ah Barokah.

b) Untuk mengetahui pengaruh kesadaran diri karyawan terhadap minat masyarakat muslim menjadi anggota menggunakan analisa regresi linier berganda memperoleh hasil nilai Sig. 0,001 dengan alpha 5\%. Sedangkan nilai beta dalam unstandardized coefficients variabel kesadaran diri karyawan menunjukkan angka sebesar 0.700. Ini berarti pada saat kesadaran diri meningkat 1 satuan, maka besarnya minat masyarakat muslim menjadi anggota adalah sebesar 0.700 satuan. Sehingga dapat dikatakan bahwa variabel kesadaran diri karyawan mempunyai pengaruh yang positif terhadap minat masyarakat muslim menjadi anggota di Koperasi Syari'ah Barokah.

Sedangkan hubungan antara interpersonal skill karyawan secara simultan yang terdiri dari atribut variabel berupa komunikasi interpersonal dan kesadaran diri terhadap minat masyarakat muslim menjadi anggota di Koperasi Syari'ah Barokah, memperoleh hasil hasil $F_{\text {hitung }}(15.204)>F_{\text {tabel }}$ (3.27) dengan nilai Sig. 0.000 dengan alpha 5\%. Hal tersebut menunjukkan bahwa kedua indikator dalam penelitian memiliki pengaruh dalam meningkatkan minat masyarakat muslim menjadi anggota di Koperasi Syari'ah Barokah. Dengan demikian, dapat disimpulkan bahwa hipotesis yang menyatakan "tidak ada pengaruh secara simultan antara variabel komunikasi interpersonal dan kesadaran diri karyawan terhadap minat masyarakat muslim menjadi anggota di Koperasi Syari'ah Barokah" tidak dapat diterima, yang berarti menerima hipotesis yang berbunyi "secara simultan ada pengaruh yang signifikan antara variabel komunikasi interpersonal dan kesadaran diri karyawan terhadap minat masyarakat muslim menjadi anggota di Koperasi Syari'ah Barokah".

Hasil analisa yang terakhir yakni uji koefisien determinasi yang menunjukkan angka $R$ Square atau koefisien determinasi $\left(R^{2}\right)$ adalah 0.465 . Sedangkan untuk regresi linier berganda yang digunakan adalah yang tertulis di Adjused R Square. Maka angka Adjused R Square adalah 0.434, artinya 43,4 $\%$ variabel terikat minat anggota dijelaskan oleh variabel bebas yang terdiri dari komunikasi interpersonal dan kesadaran diri karyawan, sedang yang 56.6\% 
sisanya dijelaskan oleh variabel lain di luar variabel yang digunakan (diteliti). Variabel yang dapat memengaruhi minat menjadi anggota tersebut dapat berupa faktor lokasi, pelayanan, produk pembiayaan, reputasi dan kualitas religius dan variabel yang lainnya. Hasil koefisien determinasi tersebut menunjukkan bahwa masih terdapat variabel independen lainnya yang dapat memengaruhiminat masyarakat muslim menjadi anggota di Koperasi Syari'ah Barokah. Variabel independen (faktor-faktor lain) yang belum diketahui ini yang akan didalami secara kualitatif.

Dalam penelitian ini, peneliti juga melakukan pendekatan kualitatif dengan menggunakan wawancara sebagai teknik pengumpulan data. Dalam hal ini peneliti mengambil 5 anggota Koperasi Syari'ah Barokah yang secara sukarela menjadi partisipan dalam penelitian ini, guna untuk mengetahui faktor apa yang paling memiliki pengaruh terhadap minat menjadi anggota Koperasi Syari'ah Barokah. Karena bagi pihak koperasi anggota adalah nyawa bagi kemajuan dan perkembangan koperasi, maka dari itu minat anggota dan calon anggota sangat penting untuk dijaga. Berikut peneliti mencoba memaparkan dalam bentuk gambar, bagaimana interpersonal skill dan faktor dominan lainnya dalam memengaruhi minat anggota.

\section{Diagram 1.}

Faktor-Faktor Yang Memengaruhi Minat Anggota

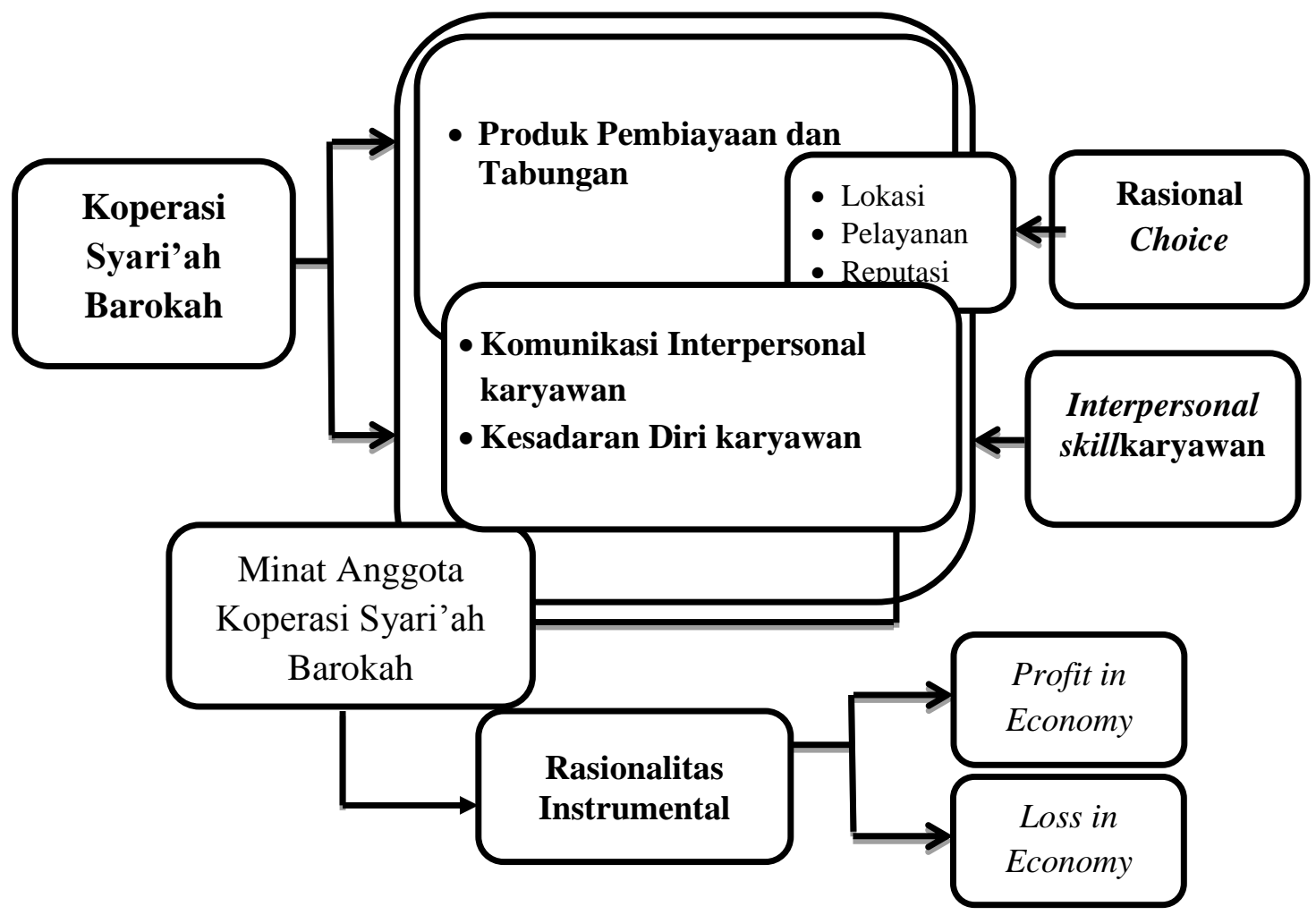


Setelah diketahui sebelumnya bahwa faktor interpersonal skill karyawan memiliki pengaruh sebesar $43,4 \%$ terhadap minat tersebut, maka tentunya akan ada faktor yang lebih dominan dibanding interpersonal skill karyawan Koperasi Syari'ah Barokah. Pendapat ini sejalan dengan data yang didapatkan oleh peneliti melalui wawancara terhadap partisipan (anggota Koperasi Syari'ah Barokah).

Dari faktor-faktor yang dibahas sebelumnya, bahwa anggota koperasi masih cenderung berfikir rasional dengan lebih mementingkan faktor kebutuhan ekonomi. Hal ini searah dengan pendapat Rochman Achwan seperti yang dikutip oleh Hardivizon yang mengurai bahwa rasionalitas sebagai tindakan ekonomi yang memiliki alasan yang masuk akal menurut pandangan pelaku bukan menurut pandangan para ahli. ${ }^{25}$ Sejalan dengan Rochman, Max weber mengkategorikan hal tersebut sebagai rasionalitas instrumental dimana tindakan individu lebih mengutamakan kepentingan diri dan memperhitungkan untung rugi dalam mengejar tujuan-tujuan ekonomi (rasionalitas). ${ }^{26}$

Untuk memahami anggota yang rasional, perlu meminjam pendapat dari Edgeworth bahwa, rasionalitas anggota yang selalu mendasarkan pilihannya pada kalkulasi ekonomi dan untung rugi. ${ }^{27}$ Dengan minat anggota untuk bergabung dengan Koperasi Syari'ah Barokah cenderung bersifat rasional, maka anggota akan cenderung bertujuan untuk memaksimalkan keuntungan yang bisa diperoleh. Adapun kalkulasi ekonomi dan perhitungan untung rugi yang dimaksudkan disini seperti, koperasi yang telahberkembang akan menjadi pilihan bagi anggota karena cenderung menguntungkan dalam hal kepercayaan dan resiko kemungkinan terjadinya kebangkrutan koperasi lebih kecil.

Kemudian dalam hal keuntungan dalam hal kemudahan mengakses lokasi, anggota menjadi lebih mudah mengawasi dan mengunjungi koperasi. Selanjutnya dalam hal pelayan seperti dengan pemberian solusi dari pihak koperasi kepada anggota apabila mengalami permasalahan akan menjadi pilihan anggota karena menguntungkan dalam hal menemukan jalan keluar.Kemudian dengan adanya kemudahan dan toleransi dalam hal pembiayaan yang diberikan oleh pihakKoperasi Syari'ah Barokah, hal ini menjadimenjadi daya tarik dan keuntungan tersendiri bagi anggota.

${ }^{25}$ Hardivizon, et.al., Religious Taste Dan Bank Choice Behaviour. Relasi Sistem Prefensi Agama dan Pilihan Konsumen terhadap Bank Syariah di Provinsi Bengkulu, (Diktis Kemenag RI: 2015), 17.

$$
\begin{aligned}
& { }^{26} I \text { bid, } \\
& { }^{27} I \text { bid, } 94
\end{aligned}
$$


Dari kecenderungan rasionalitas anggota di atas, maka peneliti dapat menyimpulkan bahwa kalkulasi kebutuhan ekonomi menjadi penting dalam memengaruhi minat anggota. Dalam hal ini yang menjadi daya tarik yang lebih dominan adalah kebutuhan akan pembiayaan yang ditawarkan oleh pihakKoperasi Syari'ah Barokah tanpa melupakan faktor penting lainnya. Dalam penelitian ini, peneliti menggunakan pendekatan kuantitatif dengan angket (kuisioner) sebagai alat pengumpul data.Serta menggunakan tingkat kesalahan sebesar 5\% dan dengan populasi anggota Koperasi Syari'ah Barokah yang mencapai 255 anggota diperoleh sampel sebanyak 38 responden. Dari sampel tersebut maka peneliti menggunakan teknik random sampling sehingga responden atau anggota memiliki kesempatan yang sama untuk menjadi sampel penelitian.

Untuk mengetahui pengaruh komunikasi interpersonal dan kesadaran diri karyawan terhadap minat masyarakat muslim menjadi anggota, peneliti menggunakan kuesioner yang telah disebar kepada anggota.Kemudian data yang telah diperoleh diuji dengan SPSS. Dari Hasil analisa uji koefisien determinasi yang menunjukkan angka $R$ Square atau koefisien determinasi $\left(R^{2}\right)$ adalah 0.465. Sedangkan untuk regresi linier berganda yang digunakan adalah yang tertulis di Adjused R Square. Maka angka Adjused R Square adalah 0.434, artinya 43,4 \% variabel terikat minat anggota dijelaskan oleh variabel bebas yang terdiri dari komunikasi interpersonal dan kesadaran diri karyawan, sedang yang 56.6\% sisanya dijelaskan oleh variabel lain di luar variabel yang digunakan (diteliti).

Hal ini diperkuat dengan data hasil data kualitatif, dimana peneliti menggunakan wawancara sebagai teknik pengumpulan data. Dalam hal ini peneliti mengambil 5 anggota Koperasi Syariah Barokah yang secara sukarela menjadi partisipan dalam penelitian ini, guna untuk mengetahui faktor apa yang paling memiliki pengaruh terhadap minat menjadi anggota Koperasi Syari'ah Barokah diluar faktor interpersonal skill. Data dari hasil wawancara tersebut didapatkan bahwa kalkulasi kebutuhan ekonomi menjadi penting dalam memengaruhi minat anggota. Dalam hal ini yang menjadi daya tarik yang lebih dominan adalah faktor kebutuhan akan pembiayaan yang ditawarkan oleh pihak Koperasi Syari'ah Barokah tanpa melupakan faktor penting lainnya. 


\section{Penutup}

Berdasarkan hasil penelitian dan pembahasan hubungan Interpersonal Skill karyawan terhadap minat masyarakat muslim menjadi anggota di Koperasi Syariah Barokah serta didukung teori-teori yang melandasi pada bab-bab sebelumnya, maka penulis mengambil kesimpulan bahwa:

Pertama, terdapat hubungan yang signifikan secara parsial antarainterpersonal skill karyawan terhadap minat anggota koperasi dimana:

a. Terlihat dari variabel komunikasi interpersonal karyawan $\left(X_{1}\right)$ memiliki $t_{\text {hitung }}$ (3.313) $>\mathrm{t}_{\text {tabel }}$ (2.03011) dengan nilai Sig. sebesar 0.002 dengan alpha 5\%. Maka dapat disimpulkan bahwa komunikasi interpersonal karyawan memiliki pengaruh yang signifikanterhadap minat masyarakat muslim menjadi anggota di Koperasi Syariah Barokah.

b. Terlihat dari variabel kesadaran diri karyawan $\left(\mathrm{X}_{2}\right)$ memiliki $\mathrm{t}_{\text {hitung }}(3.633)>$ memiliki $\mathrm{t}_{\text {tabel }}$ (2.03011) dengan nilai Sig. sebesar 0.001 dengan alpha 5\%. Maka dapat disimpulkan bahwa variabel kesadaran diri karyawan memiliki pengaruh yang signifikanterhadap minat masyarakat muslim menjadi anggota di Koperasi Syariah Barokah.

Kedua, terlihat dari hasil $\mathrm{F}_{\text {hitung }}(15.204)>\mathrm{F}_{\text {tabel }}$ (3.27) dengan nilai Sig. 0.000 dengan alpha 5\%. Hal tersebut menunjukkan bahwa secara simultan antarainterpersonal skill karyawan yang terdiri dari variable komunikasi interpersonal dan kesadaran diri memiliki pengaruh yang signifikan terhadap minat masyarakat muslim menjadi anggota di Koperasi Syari'ah. Dan dari Hasil analisa uji koefisien determinasi didapat bahwa 43,4\% variabel terikat minat anggota dipengaruhi interpersonal skill karyawan, sedang yang 56.6\% sisanya dipengaruhi oleh variabel lain di luar variabel yang digunakan (diteliti).

Ketiga, berdasarkan pengolahan data dan in-depth interviewyang telah dilakukan. terdapat faktor yang lebih dominan pengaruhnya yaitu kalkulasi kebutuhan ekonomi dalam hal ini kebutuhan akan pembiayaan (dana). Maka dapat disimpulkan bahwa anggota Koperasi Syari'ah Barokah lebih mementingkan faktor kebutuhan ekonomi tanpa melupakan faktor penting lainnya dengan didukung oleh interpersonal skill karyawan koperasi dalam memutuskan minatnya bergabung dengan Koperasi Syari'ah Barokah.

Demikian, temuan ini menegaskan bahwa nasabah atau dalam istilah populer anggota Koperasi Barokah, Curup lebih dapat dan sangat layak disebut sebagai nasabah yang kompleks. Dengan mengklasifikasikan mereka sebagai anggota yang rasional, akan membawa pada kegagalan memahami karakteristik dan differensiasi. Bahkan berujung pada kegagalan menangkap nilai sertai keyakinan yang ada di balik pilihan mereka terhadap koperasi syariah-Koperasi 
Barokah. Lantas, apa tipologi yang layak dilekatkan pada anggota Koperasi Barokah, Curup?

Statemen di atas--anggota Koperasi Syari'ah Barokah lebih mementingkan faktor kebutuhan ekonomi tanpa melupakan faktor penting lainnya dengan didukung oleh interpersonal skill karyawan koperasi dalam memutuskan minatnya bergabung dengan Koperasi Syari'ah Barokah, setidaknya menegaskan bahwa anggota Koperasi Barokah selain rasional, mereka juga mempertimbangkan alasan-alasan non ekonomi seperti agama; budaya; dan persoalan etis lainya. Kendati sejatinya score faktor non-ekonomi jauh lebih dominan ketimbang faktor kultural seperti agama, dan budaya. Tapi tidak lantas faktor yang inferior tersebut diabaikan begitu saja. Dalam konteks ini kemudian pemahaman kualitatif jauh lebih penting, agar pemaknaan terhadap apa yang tidak dapat ditangkap dan tak mampu dapat dijelaskan secara kuantitatif dapat dipahami lebih dalam melalui pendekatan kualitatif.

Dalam hubungannya dengan interpersonal skill-sebagai sebuah kemampuan yang tumbuh secara mekanik, minat konsumen untuk bergabung menjadi anggota Koperasi Barokah, tidak serta merta disebabkan oleh adanya dan baiknya kemampuan interpersonal skill karyawan Koperasi Barokah. Tapi juga disebabkan oleh bagaimana strategi pencitraan yang dibangun oleh Koperasi Barokah, dalam mengeksternalisasi diri sebagai lembaga mikrokeuangan yang islam dan berbasis syariah. 


\section{Daftar Pustaka:}

Bramantyo, R. dan Agus Tri Prasetyo, Interpersonal Skill, Bogor: Pusiklatwas BPKP, 2007

Campbell, Linda. et.al, Teabching \& Learning Through Mutiple Intelligences, Depok: Inisiasi Press, 2002.

Hardivizon, et.al., Religious Taste Dan Bank Choice Behaviour: Relasi Sistem Prefensi Agama dan Pilihan Konsumen terhadap Bank Syariah di Provinsi Bengkulu, Diktis Kemenag RI, 2015.

Hardjana, Agus, Komunikasi Interpersonal Dan Intrapersonal, Yogyakarta: Kanisius, 2003.

Kamus Besar Bahasa Indonesia, Jakarta: Pustaka Phoenix, 2007.

Kartono, Kartini, Psikologi Umum, Bandung: Mandar Sari, 1996.

Mamang Sangadji, Etta dan Sopiah, Perilaku Konsumen,Yogyakarta: Andi Offset, 2013.

Maulana, Herdiyan dan Gumgum Gumelar, Psikologi Komunikasi dan Persuasi, Jakarta Barat: @kademia, 2013.

Nazir, Moh., Metode Penelitian. Jakarta: Ghalia Indonesia, 1988.

Purwanto, M. Ngalim, Psikologi Pendidikan, Bandung: Remaja Rosdakarya, 1990.

Sutrisno, Edi, Manajemen Sumber Daya Manusia, Jakarta: Kencana, 2012.

Syah, Muhibbin, Psikologi Pendidikan, Bandung: Remaja Rosdakarya, 2009.

Usman, Husaini dan Purnomo Setiadi, Metode Penelitian Sosial, Jakarta: Bumi Aksara, 2001.

Yani Pusfiyaningsih, Linda, Interpersonal Skills, http://slideplayer.info/slide /3044809/, diakses pada 20 Januari 2016.

Ade Fitri, Bendahara, wawancara, 11 Februari 2016, 08:10 Wib. 
146 |Al-Falah: Journal of Islamic Economics, Vol. 1, No. 2: 2016 